\title{
A NEW VENTURE IN FRENCH COMPOSITION'
}

\section{By HARRY KURZ}

FOR three years $I$ have been experimenting with a now type of French composition, different from the course that is built about a text-book. Most-of the new books used for composition classes have been excellently written from the point of view of contact with the foreign country. Two American boys are launched into a voyage of discovery. The peregrinations of these innocents are set down in an interesting manner, and our students follow their adventures with the frequent and necessary interruptions of questionnaires and exercises.

The motive that guides these books is excellent. They all seek to acquaint our students in a most sympathetic manner with the foreign land. They incidentally give him current idiom while they aid the teacher with a succession of drills, grammar reviews and other paraphernalia of classroom practice. And with all these useful impedimenta the student actually travels. For elementary work these books are probably the best that can be devised, though one can imagine that the perfection of our talking machines and moving pictures will soon reveal to our students the characters themselves living the peripatetic drama on a screen, while the metallic voice of a phonograph nicely adjusted will chant the proper phrases. The teacher will then sit back with folded arms, except when he has to change the needles.

At any rate, no one seriously questions any more the value of bringing to the student in every way possible the realia of experience abroad. The professional teacher of French who has never been abroad is fast becoming extinct. Franco-American scholarships are extending the most wonderful opportunity to learn foreign living. We all have met the young teacher who has just come back from Europe and we know what has happened to his horizon line. I can mention a student who was poor in French and whom one year in France improved to such an extent that he spoke the language better than his teacher.

1 Read at the Modern Language Conference, Central Division, Iowa City. December 29, 1921. 
It is, of course, not impossible that we shall so far develop our modes of travel that it will be a matter of fact to take a class abroad every other week-end. But before that epoch arrives, we can improve a lot of advanced composition teaching. Certainly our students should learn something more than mere catch phrases that will enable them to ask their way about, buy a railway ticket and shop aux Galeries Lafayette. They should be able to live the thought-life of France and meet French people on a basis of intellectual exchange. To aid them in this, they must be surrounded with a French atmosphere right on their own campus. We must bring the mountain to Mohammed, and if faith can move mountains, the French teacher must perform the miracle and bring all of France, material and spiritual, over to the students.

Et voici comment. By a new course in French composition. I am not speaking so much of the linguistic side as the title indicates. Composition means weaving together out of elements. This course supplies the variegated elements, which are not only language forms, but ideas, pictures, information, science, art, all the mental and physical life that is actually being lived in the foreign country. Composition of France would be a more accurate title than French composition.

In aiming for this encyclopedic purpose, these are the steps one may take in method and classroom management.

1. Choose your French corner on the school campus and turn it into a little bit of France. Books, pictures, paraphernalia, a canceled passport, stamps, postcards, telegram forms, even a "Bottin" if you can afford one. Give the course in this place.

2. Plan the course so that no text book will hold the main attention of the student.

3. Instead of texts introduce, in the new composition classes, material similar to the following, all of which I am using.

a. Le Matin, a Paris daily.

b. Magazines, weekly, bi-weekly and monthly, such as: Les Annales, Je Sais Tout, Lectures pour Tous, l'Illustration, le Larousse Mensuel, la Revue Bleue, le Mercure de France, le Progres Civique. The college library orders them all. Students soon enter personal subscriptions for their favorites. 
c. A small text like Weill's "Newspaper Reader" or Pargment's "Exercices Français," to be used as a common basis for practice in pronunciation.

4. This is the method we use to assign this material.

a. Le Matin. Each student has to read the news every day in the week for a minimum of five minutes. He chooses an interlocuteur, or at our Co-ed Knox, it is more likely to be an interlocutrice, and these report to each other the items of news they have read. A report sheet held by the librarian helps to check up every day on this part of the work.

b. Magazines. In the study of the magazines the student has great freedom. There are two main sections to the work, written and oral. The written work consists of a good weekly report, minimum two pages, (I have received 6 and 7), in which the student reports an article he has read. His choice is untrammeled, except that he has to use a different magazine for three consecutive weeks before he can revert to one already used. Mistakes in these reports are underlined and the papers returned to the students. They should then be returned to the teacher corrected.

These weekly reports develop in a way that is amazing. They become fluent and interesting résumés of stories and serious articles. The scientific student of course reports the scientific articles. Likewise the musical student or the history major or the economics specialist, all seek out their interest in these various magazines. Incidentally the teacher's own information is replenished by these streams which converge under his red-underlining fountain pen.

Those who enter into the spirit of French writing know the interest of the short article or story, sustained to the end by the clear flow of language, with often a penetrating thought lurking behind a play of words, or a gleam of humor in the twist of an idiom. These things are contagious. By dint of contact with them the students catch something. They inject their own research and experience and point of view. Here is an assortment of themes that I corrected at one sitting: Les Rayons UltraVialets: les Salaires augmentent moins vite que le prix de la vie; Pathologie Verbale, études de mots; l'Education physique dans les écoles: la Loi morale du Travail; la Valeur pédagogique des contes de 
fées. These beside such hair-raising episodes as: La Momie mystêrieuse; le Cercueil du Mandarin; le Pied du Diable.

c. Some part of the hour, not more than ten minutes, is spent in drill. Mistakes of a general character occurring in the written themes are taken up. A text such as mentioned above serves as an excellent basis for practice in pronunciation.

5. The main part of the recitation is given over to the students' oral reports on readings. The readings are selected from among the newly arrived magazines, a certain number for each week. A careful list of new words and expressions is made out, about 100 a week, and a number of copies of this list are left at the library. The first student to read the articles jots down definitions on the original vocabulary sheet and others, following him, are saved this time. The definitions are verified by the teacher. The student has read and re-read the assignment and studied the new words. He is then given four minutes in class to tell without notes the gist of his article. Different students reading different magazines vary this program for the day but by the end of the week all have read the same articles and can talk about any one of them. The number of assignments varies with the number of recitation periods in the week, the type of students and, of course, with the size of the articles. At the end of four weeks the student takes a written quiz on the vocabulary acquired and the content of the articles read. Each hour his oral report shows how well he has assimilated his new vocabulary which he is encouraged to use extensively. I have had students utter on the floor such expression as: acquérir un bout d'expérience; ne pas avoir l'ombre d'une initiative, se débrouiller seul; mettre quelqu'un en tire-bouchon; vaquer à la besogne; payer d'audace; expressions eminently idiomatic transforming the students' specch into a gay and living thing.

The program may be varied sometimes by permitting two or more students to make their oral reports together. This is useful especially in the case of a play. The unforeseen always awaits you in a performance of this sort, where the student has not studied a part by heart, but knows the plot and follows it out with his comrades--one might say a pedagogic variation of the commedia dell'arte. One day in my class a demure little maid 
posing as a rich widow proposed to a young marquis. She did it with such ardor and peremptoriness that the poor nobleman yielded a little sooner than his allotted time warranted. Our football star one day assumed the rôle of Charlot and a young lady, his devoted admirer, showed him about Paris. Another time a young sailor whose French was none too voluble was exposed with some abler comrades to the terrors of a tempest on a raft. To end his agony, linguistic mainly, he bent down, drank salt water, and informed his comrades he was dead.

All this sounds playful enough. Please remember that the main work of the course is the individual expression in a given time of the gist of a serious article or well-written short story. While the student speaks, his comrades note mistakes and are always given a chance to make the corrections. The hours are interesting and encouraging to the students involved. They feel that they are gaining.

It is to be noted that the course is not entirely oral. I have already mentioned the weekly report. In addition, the students bring in each hour assigned exercises in the text book chosen for common practice. And finally, each member of the class is appointed a reporter and hands in every week items in French of general interest to the student body These are published in a column entitled Crême de Menthe in the weekly college paper.

One of the results of a composition course of this type is to show to the student that France is working along the very line which interests him. He realizes, if he is a scientist, that a prodigious exploration is going on which is vital to him. Personal subscriptions to magazines after this course are numerous. Only a few days ago onc of my students, a Sophomore, asked me to correct a letter that he had composed addressed to the Librairie Champion, ordering the four volumes of Joseph Bédier's studies of epics and chansons de gesle. He was interested in Charlemagne from his course in medieval history. In his French composition course he had read of Bédier's admission into the Academy and he had found out that Bédier was a good authority for him to consult in the ficld which held his interest.

It is hard to realize that in this course the acquisition of vocabulary will become an exciting game. The impression one 
gets as one reads with constancy periodical French is its extreme facility, its flows, its ever-changing rythms, and its wonderful power for clarity. Here and there the student will garner some picturesque turn of phrasing oftimes bordering on argot, which, haunting his imagination, will crop out in his own lingo unexpectedly. He is bound to have some adventure with: laisser percer le boul de l'oreille; with ce vieux raseur; with un clignement de ouistiti. He will adopt an adverb like-darwiniquement, and a verb, relic of the war, like-alerter. He gets the realization that French is not a static textbook language. It is flowing on, it is spoken and written daily by millions, many of whom read the very magazines we are reading and of whose existence these periodicals are a proof. One young man put it well when he told me that he had an uncanny feeling every time he received his personal copy of Les Annales. It proved to him anew that France was just across the water, living and producing these things that he was getting. He is a poor boy working his way through but I know now that one of his summers will be spent working his way over to the land of his dreams.

There are two more developments to this composition course toward which we are working. France needs sympathetic and understanding friends everywhere in our country. This type of course starts them growing. But even more, my class has already the opportunity through the interest of local editors to furnish regular French stuff, that is, items of news about France. The students brought into contact with her by her publications are to some extent ready to explain her to our people. Our citizens should know what Rudyard Kipling said when he was recently made a doctor by the University of Paris. Americans should note the death of Camille Saint-Saens and of Emile Boutroux and what these men represent in French civilization. Items of this kind have already appeared in Illinois papers.

Another feature which may be introduced next year is a subscription to one of the numerous collections, such as the Bibliotheque Française which is under the auspices of the Alliance Française, and which for ten dollars per annum sends a modern work of literature every month with appropriate critical material. While some of the magazines publish "Pages Choisies" from new works, 
one wants to see the students handle the familiar paper-bound volume fresh from France. ${ }^{2}$

One final remark. This venture in French composition is the most exacting course I have ever known. One must not count the hours of preparation for it. One will have to read the magazines and books to keep up with the class. And so I would state as prime requisites for those who would try it: (a) ability to give twice as much time to preparation as the conventional course requires; (b) the ambition to speak living French; (c) a profound love for France of to-day.

Knox College

Galesburg, Ill.

${ }^{2}$ Since this paper was read, the students in this course decided to buy one novel each and present them finally to the college library after they were through with them. Their scheme is to read a novel each month. The following selection was made for the first order:

Duhamel, Entretiens dans le humulte; Benoft, l'A llantide; Bordeaux, la Chair et l'espril; Boylesve, Elise; Tinayre, Perstphone; Bourget, Drame dans le monde; Hémon, Marie Chapdelaine; Maran, Batouala. 